\title{
O que os psiquiatras fazem?
}

\author{
What does the psychiatrists does?
}

Carol Sonenreich, Giordano Estevão

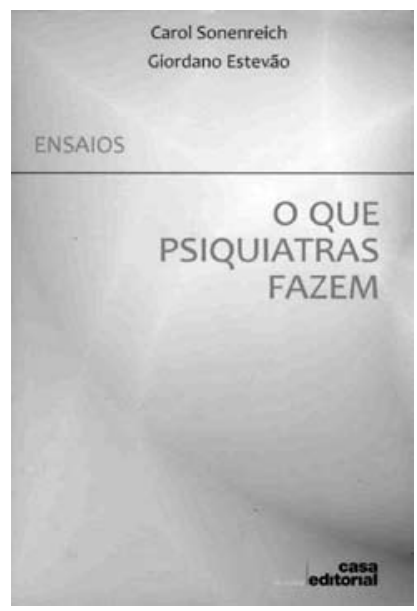

O livro "O que os psiquiatras fazem? - Ensaios, 2007 - de Carol Sonenreich e Giordano Estevão é dividido em dez longos capítulos, além da introdução, totalizando 367 páginas de extensão. Trata-se de amplo conjunto de reflexões e críticas de assuntos importantes, dos quais se destacam as classificações oficiais, o delírio, as dependências, a depressão e as várias formas de psicoterapia, inclusive a psicanálise.

Os autores, psiquiatras clínicos muito experientes, conhecidos e responsáveis por inúmeros trabalhos de alta qualidade, fazem levantamento bibliográfico comentado e criticado de praticamente todas as correntes que utilizam a psiquiatria, no seu dia-a-dia, na prática médica. Todos os capítulos cuidam um pouco de história, da evolução de conceitos e como se encontram hoje as várias teorias. O viés no sentido fenomenológico existencial é claro e dissertado sempre em muito bom nível, agradável e um tanto sofisticado. O texto "Fazemos psiquiatria para pessoas no seu mundo", no fim da introdução, é emblemático do que afirmamos na frase anterior.

Depois da introdução, os autores se esforçam e, acreditamos que conseguem, optam pela escolha da psiquiatria científica, a qual necessita ser formulada em termos comunicáveis que possam ser avaliados e criticados pela coletividade profissional.

Comentando as classificações oficiais, acentuam que a fenomenologia recomenda, para fazer descrições das nossas percepções, o "retorno à experiência singular do sujeito" e, põese a favor da medicina das alterações psíquicas. A doença mental deveria ser o instrumento para o trabalho dos psiquiatras. Assim, a psiquiatria poderia ser mais adequadamente estudada e tratada, pensando em estruturas, sistemas e configurações.

Fazem e discutem inúmeras críticas ao sistema DSM.

No capítulo do delírio, um dos mais longos do livro, há críticas aos conceitos de esquizofrenia (construto, inconsistente), TOC, fobia (psicastenia) e idéias delirantes. A maior crítica às teorias existentes sobre esquizofrenia é que elas seriam, terapeuticamente, estéreis em relação à "psicastenia". Os autores fazem forte crítica aos conceitos de fobia e TOC com os quais seria impossível trabalhar da forma como são classificados pela CID-10 e DSM-IV. Fobia e obsessão estariam ali muito indefinidas. O diagnóstico de delírio, em última análise, seria feito nos casos caracterizados pela perda da comunicação lógica.

Em relação às chamadas dependências, poder-se-ia dizer que, resumindo as idéias dos autores, aqui, tudo é difícil. O tratamento é precário. Poucas são as recuperações. A forte rejeição por parte de certos grupos que nega que o alcoolismo não seja uma doença. Não se pode sequer prever quem vai ser dependente. O capítulo é resumido com a seguinte frase (a nosso ver corretíssima): "O tratamento das doenças mentais decorrentes do uso de substâncias psicoativas permanece tarefa psiquiátrica e, neste sentido, temos que agir para ultrapassar os recursos atuais, tão pouco satisfatórios".

No campo das demências, o pensamento dos autores se resume na introdução, ou seja, os conceitos, as direções e os métodos de investigação estão em contínuo movimento, não havendo posição nenhuma que satisfaça as necessidades dos pensadores e da clínica, nenhuma que constitua plataforma de aceitação geral. Enfim, os pesquisadores não conseguiram, até agora, vencer as dificuldades conceituais manifestas nos resultados variáveis dos estudos empíricos.

Mais uma vez, no capítulo "Depressão", os autores fazem fortes críticas às classificações oficiais, alegando ser absolutamente necessária a revisão da classificação dos transtornos depressivos, a fim de evitar a atual confusão conceitual. Também é amplamente discutida a 
questão do modelo dimensional versus modelo do continuum, com suas vantagens e desvantagens. Acabam os autores por conceituar a depressão como a lentificação em campo vivencial estreitado.

Os autores dissertam sobre as várias formas de terapia, inclusive a psicanálise, que não poderia ser avaliada. Fazem revisão das práticas psicanalíticas e de vários autores dessa linha de pensamento, comparando os vários métodos psicoterapêuticos por eles adotados, criticando todos, e reconhecendo o atual baixo nível da discussão existente, ainda hoje, entre inimigos e adeptos da psicanálise.

Em seguida, discutem sobre objetividade versus subjetividade, apontando grupos de autores e várias teorias a respeito, concluindo que "científico" não exclui "subjetivo", arrematando o assunto com a seguinte declaração: "Enquanto uns excluem do campo das ciências o subjetivo e exigem caráter empírico para validar um diagnóstico, escolher uma terapia, outros rejeitam essa posição, declarando-as desnecessária e impossível".

Finalizando o trabalho, apresentam sua "opção psicoterapêutica", afirmando que seu modo de praticar, entender e conceber a psicoterapia se norteia por trabalhos que poderiam ser chamados fenomenológico-existenciais.

Decididamente o livro atenderá aos interesses de psiquiatras das mais variadas formações pela qualidade de seu conteúdo.

Jorge Adelino Rodrigues da Silva

Departamento de Psiquiatria e Medicina Legal da Faculdade de Medicina da Universidade Federal do Rio de Janeiro (UFRJ) 